\title{
WOMEN AT THE LEVEL OF MANAGEMENT AGENCY CONFLICT MECHANISMS AND FINANCIAL PERFORMANCE
}

\author{
Lukas Surjaatmaja ${ }^{1}$ \\ Hendra Wijaya ${ }^{2}$ \\ Business Faculty, Accounting Department, \\ Widya Mandala Catholic University Surabaya- Indonesia \\ Corresponding author: Lukas Surjaatmaja \\ lukas_atmaja@ukwms.ac.id
}

\section{A R T I C L E I N F O}

Article history:

Received : 2 Aug 2020

Revised : 17 Aug 2020

Accepted : 22 Aug 2020

Key words:

female top management, managerial ownership, institutional ownership, debt

DOI: https://doi.org/10.33508/rima.v3i1.2743

\begin{abstract}
A B S T R A C T
This study analyzes the effect of female representation in top management, agency conflict mechanism on firm performance in Indonesia Manufacturing Firms. Agency conflict in this reseach consist of managerial ownership, institutional ownership, and debt. The sample of this study consist of 90 manufacturing firms over the period 2013-2017. This study measures firm performance with return on asset and return on equity. Data on this research were analyzed using multiple regression. This study found that female representation in top management and managerial ownership do not affect firm performance. This study also found that institutional ownership positively affects the firm performance and debt negatively affects the firm performance
\end{abstract}

\section{INTRODUCTION}

The thing that needs attention in creating the company's financial performance is company management, an agent who gets delegation from the company owner (principal) to decide the company. One of the exciting issues in company management is the gender of the company management. Hambrick and Mason (1984) suggest that the company's performance is determined through the manager's background characteristics. Hambrick (2007) indicates that the factors of managers affect the discretion of company managers. Women can improve company performance because women's characters, such as women, are more risk averse than men. Perryman, Fernando, \& Tripathy (2016). Welbourne, Cycyota, and Ferrante (2007) suggest that women have better innovation traits and better problemsolving processes that positively contribute to the company. This is supported by research conducted by Perryman et al.
(2016), Cambrea, Lussana, Quarato, and Varacca Capello (2017), Giraldez-Puig, and Berenguer (2018). They found women at the top level have a positive effect on financial performance. Conflicting results were found by Gallego-Álvarez, García-Sánchez, and Rodríguez-Dominguez (2010) and Solakoglu and Demir (2016). Women at the top level did not affect the company's financial performance.

Agency conflict is a critical issue to pay attention to regarding the company's financial performance. Agency conflict is a conflict that occurs between company owners and managers Jensen and Meckling (1976). Agency conflicts can arise when managers of the company make decisions that generate profits for managers themselves and ignore the company owners' interests to harm the company owners Jensen and Meckling (1976). This causes the financial conflict mechanism to be an essential matter to pay attention to reduce agency conflicts. 
According to Jensen and Meckling (1976), one of the mechanisms of agency conflict is managerial ownership. Managerial ownership is ownership of shares owned by company managers. Managerial ownership can align interests between owners and managers of the company. This is because, with managerial ownership, the manager is also the owner of the company. This is supported by research produced by Abu Haija and Alrabba (2017) and Nguyen, Nguyen, Nguyen, and Tran (2017), who find managerial ownership positively affects financial performance.

The second conflict mechanism was in institutional ownership. Institutional ownership can reduce agency conflicts due to company managers (Jensen \& Meckling, 1976). Chung and Zhang (2011) suggest that the greater institutional ownership in company shares indicates a good governance structure. This is also supported by research conducted by Esther, Symon, Lawrence, and Sifunjo (2016), Abu Haija and Alrabba (2017), Kao, Hodgkinson, and Jaafar (2018), which found that institutional ownership has a positive effect on financial performance.

The third conflict mechanism is debt. According to Jensen \& Meckling (1976), debt is an agency conflict mechanism because, with debt, there will be supervision from creditors on decision making taken by company managers. Jensen (1986) also argues that by using debt, managers will be careful in making decisions because company managers must return the principal and interest on the debt that has been used. This is also supported by research conducted by Achmad and Amanah (2014), Sartini and Purbawangsa (2014), and Dewi and Wirasedana (2018), who found that debt has a positive effect on firm value.

The opposite results regarding the effect of agency conflict mechanisms, namely managerial ownership, institutional ownership, and debt on company performance on financial performance, are obtained from the research of Khamis,
Hamdan, and Elali (2015), Al-Matari, AlMatari, and Mohammed (2017). They found that Managerial ownership does not affect financial performance. Herdjiono and Sari (2017) found that institutional ownership harms financial performance. Similar research on institutional ownership was also found by AL-Najjar (2015) and Khamis et al. (2015), who found that institutional ownership does not affect financial performance. The opposite research results regarding the impact of debt on company performance were found by Javed, Younas, and Imran (2014), who found that debt did not affect financial performance, and Pandey and Sahu (2019). They discovered that debt hurt company performance.

Based on different results obtained from previous studies on the influence of women on top-level management, managerial ownership, institutional ownership, and debt on financial performance. Therefore, this study surveyed the impact of female directors on upper-level control, managerial ownership, and institutional ownership on companies' financial performance in manufacturing companies listed on the Indonesia Stock Exchange. In this research, manufacturing companies were chosen because they have the largest proportion of companies listed on the Indonesia Stock Exchange. It is essential to pay attention to improving financial performance, especially concerning women at the top management and managerial ownership, institutional ownership, and debt, which are mechanisms of agency conflict.

\section{THEORICAL BASIS}

Hambrick and Mason (1984) explain that leaders' strategic decisions significantly affect the company's output. The leader's characteristics affect how the leader interprets a condition and the decisions made in responding to these conditions. Gender diversity issues, which are unique characteristics of a leader, continue to develop as a value-driver in an organizational structure and corporate 
governance (Marinova, Plantenga, \& Remery, 2016). Women's role in a board of directors can reduce the potential for information bias in strategic decisionmaking (Francoeur, Labelle, \& SinclairDesgagné, 2008). The presence of women on the board of directors indicates a broad understanding of the market and consumers, thereby enhancing its overall reputation and value. Several studies have also stated that female directors are more critical and careful, have more thoroughness than men, show collaborative skills and participatory leadership, and are more active in attending board meetings (Adams \& Ferreira, 2009; Eagly \& Johnson, 1990; Kusumastuti \& Sastra, 2007)

With various innovations and contributions from women directors, it is expected that the company's performance will increase to affect financial performance. This is supported by research conducted by Perryman et al. (2016), Cambrea et al. (2017), Giraldez-Puig, and Berenguer (2018). They found that women at the top level of management have a positive effect on financial performance. Based on the description that has been explained, the first hypothesis of this study is formulated as follows:

H1: Women at the top level of management have a positive effect on financial performance

Information asymmetry in agency relationships is the number of differences in interests that the principal and agent have. One of the mechanisms that can minimize the difference in interests is managerial ownership, where part of the company's license is owned by the management (Sintyawati and Dewi, 2018). With managerial ownership, the government avoids opportunistic actions because every decision that is made affects its welfare, acting as a shareholder.

By participating in part of the company, management is increasingly motivated to develop the company. It is hoped that the company's financial performance will also increase and the government's increasing ownership. This is supported by the findings of Abu Haija and Alrabba (2017) and Nguyen et al. (2017), which shows the positive effect of managerial ownership on financial performance. Based on the explanation above, the second hypothesis of this study is formulated as follows:

H2: Managerial ownership has a positive effect on financial performance

Sintyawati and Dewi (2018) define institutional ownership as share ownership owned by institutional investors, such as banks, insurance companies, pension fund companies, and financial companies. Institutional ownership is seen to reduce agency problems because principals receive institutional investors' assistance to oversee management's performance, which acts as an agent (Jensen \& Meckling, 1976).

With some of the ownership held by institutional investors, it is hoped that supervision will be more useful to anticipate forms of management actions and decisions that are not following the principals' interests. The existence of tighter oversight from institutional investors encourages management to carry out their duties to improve its financial performance properly. This is also supported by Esther et al., 2016; Abu Haija and Alrabba (2017), Kao et al. (2018), who found that institutional ownership positively affects financial performance. Based on the description above, the third hypothesis of this study is formulated as follows:

H3: Institutional ownership has a positive effect on financial performance

In supporting company funding, management must consider the form and composition of its most appropriate financing. The government can use both internal and external funding sources, where each form of funding has different risks and consequences. Using external funding, debt; It is expected that the company can improve company performance through the tax-deductible effect (Achmad \& Amanah, 2014). Debt financing results in loan interest, reducing 
taxable income figures, thereby increasing its net profit.

Debt funding can also be used to reduce agency problems because of creditors' supervision regarding management decision-making (Jensen \& Meckling, 1976). The creditors' responsibility results in leadership from creditors to ensure that the company can pay adequate debt. The principal can use this to oversee management performance because creditors' supervision makes management more careful in making decisions to improve the company's performance in the future. Similar research also supports that debt positively affects firm value (Achmad \& Amanah, 2014; Dewi
\& Wirasedana, 2018; Sartini \& Purbawangsa, 2014).

H4: Debt has a positive effect on financial performance.

\section{METHOD}

Population and Sample

The population of this research is manufacturing companies listed on the Indonesia Stock Exchange. In this study, sampling using a purposive sampling technique with the criteria 1) manufacturing companies listed on the Indonesia Stock Exchange during 2013-2017 2) financial statements published in rupiah 3) companies have positive equity.

\begin{tabular}{|l|c|}
\hline \multicolumn{1}{|c|}{ Criteria } & Total \\
\hline $\begin{array}{l}\text { Population: manufacturing companies listed on the Indonesia } \\
\text { Stock Exchange 2013-2017 }\end{array}$ & 134 \\
\hline $\begin{array}{l}\text { The company does not meet the purposive sampling criteria: } \\
\text { (1) The company is registered with IDX for the period 2013-2017 } \\
\text { and has complete data }\end{array}$ & 10 \\
(2) Financial reports published in rupiah & 27 \\
(3) The company has positive equity & 7 \\
\hline Companies that meet the criteria for purposive sampling & 90 \\
\hline Observation period & 5 \\
\hline Total observations & 450 \\
\hline Outlier & 21 \\
\hline The full sample was & 429 \\
\hline
\end{tabular}

\section{Method of Collecting Data}

The data in this study were collected using documentation techniques. This study's documentation was carried out by collecting financial data and ownership of manufacturing companies listed on the Indonesia Stock Exchange in 2013-2017.
Data Analysis Technique

The data in this study were processed using the following regression equation:

$$
\text { KKPit }(\text { ROA }, \text { ROE })=\alpha+\beta 1 W T A i t+\beta 2 \text { KMAit }+\beta 3 \text { KINit }+ \text { B3UTGit + }
$$

Information:

KKP: Financial Performance WTA: Women in Upper Management KMA: Managerial Ownership KIN: Institutional Ownership UTG: Debt

\section{UPR: Company Size}

The dependent variable in this study is financial performance. Financial performance in this study is measured using the return on assets (ROA) and return on equity (ROE). ROA in this study is 
calculated using the formula net income divided by total assets, while ROE is computed using net income divided by equity.

This study's independent variables are women at the top level of management, managerial ownership, institutional ownership, and debt. Women in top management are measured using the number of women in upper management divided by the company's number of power. Managerial ownership is calculated using the number of shares owned by the company's management divided by outstanding shares. In this study, institutional ownership is measured using the number of shares held by bank institutions, mutual funds, insurance companies, and pension funds divided by the number of shares outstanding. Debt in this study is measured using total debt divided by total assets.

The control variable in this study is company size. Company size in this study is measured using the natural logarithm of the company's total assets.

\begin{tabular}{|c|c|c|}
\hline Variable & Equation & Source \\
\hline \multirow[t]{2}{*}{ Financial Performance (ROA) } & Net Profit & \multirow{2}{*}{$\begin{array}{l}\text { Khamis et al. (2015) } \\
\text { Yazdanfar \& Öhman, (2015) }\end{array}$} \\
\hline & Total Assets & \\
\hline \multirow[t]{2}{*}{ Financial Performance (ROE) } & Net Profit & \multirow[t]{2}{*}{ Kao et al. (2018) } \\
\hline & Total Equity & \\
\hline \multirow{3}{*}{$\begin{array}{l}\text { Women in Upper } \\
\text { Management (WTA) }\end{array}$} & The Number of Women in Upper & \multirow{3}{*}{$\begin{array}{l}\text { Cambrea et al. (2017) } \\
\text { Perryman et al. (2016) }\end{array}$} \\
\hline & Management & \\
\hline & The Number of Company Management & \\
\hline \multirow{3}{*}{$\begin{array}{l}\text { Managerial Ownership } \\
\text { (KMA) }\end{array}$} & The Number of Shares Owned by & \multirow{3}{*}{$\begin{array}{l}\text { Khamis et al. (2015) } \\
\text { Abu Haija dan Alrabba } \\
\text { (2017) }\end{array}$} \\
\hline & Company Management & \\
\hline & The Number of Shares Outstanding & \\
\hline \multirow{4}{*}{$\begin{array}{l}\text { Institutional Ownership } \\
\text { (KIN) }\end{array}$} & The Number of Shares Owned by & \multirow{4}{*}{$\begin{array}{l}\text { Khamis et al. (2015) } \\
\text { Abu Haija dan Alrabba } \\
\text { (2017) } \\
\text { Kao et al. (2018) }\end{array}$} \\
\hline & Institution & \\
\hline & The Number of Shares Outstanding & \\
\hline & & \\
\hline \multirow[t]{2}{*}{ Debt (UTG) } & Total Debt & \multirow{2}{*}{$\begin{array}{l}\text { Khamis et al. (2015) } \\
\text { Perryman et al. (2016) }\end{array}$} \\
\hline & Total Assets & \\
\hline Company Size (UPR) & Ln (Total Assets) & $\begin{array}{l}\text { Khamis et al. (2015) } \\
\text { Yazdanfar dan Öhman } \\
(2015) \\
\text { Giraldez-Puig dan } \\
\text { Berenguer (2018) }\end{array}$ \\
\hline
\end{tabular}

\section{RESULT}

The data used in this study are financial performance (ROA, ROE), women at the top level of management (WTA), managerial ownership (KMA), institutional ownership (KIN), debt (UTG), and company size (UPR). The results of the descriptive statistics of this study can be seen in table 1 . 
Table 1. Descriptive statistics

\begin{tabular}{|l|c|c|c|c|}
\hline \multicolumn{1}{|c|}{ Variable } & Average & Std.Deviation & Maximum & Minimum \\
\hline Financial Performance (ROA) & 0,0543 & 0,0706 & 0,3120 & $-0,1358$ \\
\hline Financial Performance (ROE) & 0,0847 & 0,1131 & 0,3998 & $-0,3036$ \\
\hline Women in Upper Management (WTA) & 0,1022 & 0,1418 & 0,5833 & 0,0000 \\
\hline Managerial Ownership (KMA) & 0,0154 & 0,0406 & 0,2460 & 0,0000 \\
\hline Institutional Ownership (KIN) & 0,2469 & 0,2536 & 0,9254 & 0,0000 \\
\hline Debt (UTG) & 0,4397 & 0,1946 & 0,8849 & 0,0662 \\
\hline Company Size (UPR) & 28,2704 & 1,6082 & 33,3202 & 24,4142 \\
\hline
\end{tabular}

Source: Processed data

Table 1 shows that the financial performance variable (ROA) has a minimum value of -0.1358 and a maximum value of 0.312 and the mean and standard deviation values are 0.0543 and 0.0706 , respectively. This shows that the sample of this study, on average, can obtain a net profit of $5.43 \%$ of the total assets it owns. The financial performance variable (ROE) has a minimum value of -0.3036 and a maximum value of 0.3998 , and the mean and standard deviation values are 0.0847 and 0.131 , respectively. This shows that the sample of this study, on average, can obtain a net profit of $8.47 \%$ of the total equity it has. Women in Upper Management (WTA) show a minimum score of 0.0000 and a maximum value of 0.5833 and mean and standard deviation of 0.1022 and 0.1418 . This indicates that the number of women at the top management level is only $10.22 \%$ of the sample companies' total top management. The agency conflict mechanism, namely managerial ownership (KMA) and institutional ownership (KIN), show the following results: managerial ownership has a minimum value of 0.0000 and a maximum value of 0.2460 and an average and standard deviation 0.0154 and 0 , 0406. At the same time, institutional ownership shows a minimum amount of 0.0000 and a maximum value of 0.9254 and the mean and standard deviation of 0.2469 and 0.2536 . This indicates that of the total outstanding shares, $1.54 \%$ of shares are owned by management, and institutional investors own $24.69 \%$. The debt variable (UTG) has a minimum value of 0.0662 and a maximum value of 0.8849 , and an average value and standard deviation of 0.4397 and 0.1946. This shows that the sample companies in this study have an average debt of $43.97 \%$ of total assets owned.

Table 2. Regression Analysis Results

Financial Performance Measured Using ROA

\begin{tabular}{|l|c|c|c|c|}
\hline \multicolumn{1}{|c|}{ Variable } & Coefficient & $\begin{array}{c}\text { Std. } \\
\text { Error }\end{array}$ & $\begin{array}{c}\text { t- } \\
\text { Statistic }\end{array}$ & Sig. \\
\hline Women in Upper Management (WTA) & $-0,0241$ & 0,0297 & $-0,8104$ & 0,4182 \\
\hline Managerial Ownership (KMA) & 0,0816 & 0,0939 & 0,8689 & 0,3854 \\
\hline Institutional Ownership (KIN) & 0,0456 & 0,0191 & 2,3840 & 0,0176 \\
\hline Debt (UTG) & $-0,1791$ & 0,0265 & $-6,7661$ & 0,0000 \\
\hline Company Size (UPR) & 0,0075 & 0,0030 & 2,5226 & 0,0120 \\
\hline F & \multicolumn{4}{|c|}{$0,02,7627$} \\
\hline Sig-F & \multicolumn{3}{|c|}{0,3279} \\
\hline Adj R2 & \multicolumn{3}{|c|}{} \\
\hline
\end{tabular}

Source: Processed data 
Financial Performance Measured Using ROE

\begin{tabular}{|l|c|c|c|c|}
\hline \multicolumn{1}{|c|}{ Variable } & Coefficient & Std. Error & $\begin{array}{c}\boldsymbol{t} \text { - } \\
\text { Statistic }\end{array}$ & Sig. \\
\hline Women in Upper Management (WTA) & $-0,0252$ & 0,0484 & $-0,5197$ & 0,6036 \\
\hline Managerial Ownership (KMA) & 0,1073 & 0,1468 & 0,7311 & 0,4651 \\
\hline Institutional Ownership (KIN) & 0,0864 & 0,0335 & 2,5826 & 0,0101 \\
\hline Debt (UTG) & $-0,1780$ & 0,0457 & $-3,8981$ & 0,0001 \\
\hline Company Size (UPR) & 0,0098 & 0,0048 & 2,0492 & 0,0411 \\
\hline F & \multicolumn{4}{|c|}{0,0000} \\
\hline Sig-F & \multicolumn{5}{|c|}{0,1770} \\
\hline Adj R & \multicolumn{4}{|c|}{} \\
\hline
\end{tabular}

Source: Processed data

In table 2, it can be seen that the influence of women at top-level management on financial performance. In Table 2, using ROA, it can be seen that the significance level is 0.4182 and the significance level using ROE is 0.6036 . This shows that the significance level is $>0.005$, and women at the top level have no effect on financial performance, so that the first hypothesis in this study is rejected. This study's results are supported by Solakoglu and Demir's (2016) research and GallegoÁlvarez et al. (2010). Women at the upper management level do not affect the company's financial performance because women's proportion is still small in companies in Indonesia. It can be seen in the descriptive statistics in this study that an average of only $10.22 \%$ so that it has not been able to influence financial performance. This study contradicts the research conducted by Perryman et al. (2016), Cambrea et al. (2017), Giraldez-Puig, and Berenguer (2018). They found that women at the top level of management have a positive effect on financial performance.

In table 2, it can be seen that the effect of managerial ownership on financial performance. In Table 2, using ROA, it can be seen that the significance level is 0.3854 and the significance level using ROE is 0.4651. This shows that the level of significance $>0.005$ and managerial ownership does not affect financial performance, so that the second hypothesis of this study is rejected. The results of this study are supported by research conducted by Khamis et al. (2015), Al-Matari and AlArussi (2016), and Obembe, Olaniyi, and Soetan (2016). This is because managerial ownership in Indonesia is still small in companies in Indonesia. The descriptive statistics of this study indicate that the average administrative right is $1.54 \%$. This causes managerial ownership to be unable to align the interests between owners and managers in the company. Similar research is produced by Abu Haija and Alrabba (2017) and Nguyen et al. (2017), who found that managerial ownership positively affects financial performance.

In table 2, you can see the results of this study. In Table 2, using ROA, it can be seen that the significance level is 0.0176 and the significance level using ROE is 0.0101 . This shows that the level of significance is $<0.005$ and institutional ownership has a positive effect on financial performance so that the third hypothesis of this study is not rejected. This study's results are supported by research conducted by Esther et al., 2016 and Kao et al. (2018). This shows that the supervision carried out by institutional ownership in the company can run effectively and reduce agency conflicts in the company so that the company's financial performance can improve. The opposite research results were found by AL-Najjar (2015) and Khamis et al. (2015), who found that institutional ownership harms company performance. Herdjiono and Sari (2017) also found conflicting results; namely, institutional ownership did not affect financial performance. 
In table 2, you can see the results of this study. In Table 2, using ROA, it can be seen that the significance level is 0.0000 and the significance level using ROE is 0.0001 . This shows that the significance level is $<0.005$, and debt harms financial performance so that the fourth hypothesis of this study is rejected. The results of this study are supported by research conducted by Yazdanfar and Öhman (2015), Nwude, Itiri, Agbadua, and Udeh (2016), Abu Haija and Alrabba (2017), which found that debt harms company performance. This shows that the creditor carries out the higher the debt, the more supervision. Supervision carried out by creditors causes the company's management to be less flexible in making decisions that exist by the company because it is limited by creditors, leading to a decline in company performance. This is also supported by Stulz (1990). The conflicting results found by Javed et al. (2014) found that debt does not affect financial performance. Achmad and Amanah (2014), Sartini and Purbawangsa (2014), and Dewi and Wirasedana (2018) also found the opposite result. Namely, debt has a positive effect on company performance.

\section{CONCLUSIONS}

Based on the analysis, this study provides results. Namely, women at the top management and managerial ownership level do not affect financial performance, institutional ownership has a positive effect on financial performance, and debt harms financial performance.

This research has implications for the things that investors need to pay attention to when making investment decisions. Institutional ownership as an agency conflict mechanism is an important thing to pay attention to because it can improve company performance. Higher debt to the company can reduce company performance.

This study has limitations. This study only looks at upper-level management's characteristics only in terms of gender and agency conflict mechanisms are limited to managerial ownership, institutional ownership, and debt. Subsequent research, namely research, can be carried out by paying more attention to upper-level management characteristics apart from genders, such as the size of the board of directors, tenure of directors, age of directors, and educational background of directors. Meanwhile, the company agency conflict mechanism can add a board of commissioners and an audit committee as part of corporate governance.

\section{REFERENCE}

Abu Haija, A. A., \& Alrabba, H. M. (2017). Relationship between ownership structure and financial performance. Corporate Ownership and Control, 14(3), 393-398. https://doi.org/10.22495/cocv14i3c 2art13

Achmad, S. L., \& Amanah, L. (2014). Pengaruh Investasi,Keputusan Pendanaan,Kebijakan Dividen,Dan Kinerja Keuangan Terhadap Nilai Perusahaan manufaktur yang terdaftar di Bursa Efek Indonesia selama periode 2010-2012. Jurnal Ilmu E Riset Akuntansi, 3(9), 1-15.

Adams, R. B., \& Ferreira, D. (2009). Women in the boardroom and their impact on governance and performance. Journal of Financial Economics, 94(2), 291-309. https://doi.org/10.1016/j.jfineco.20 08.10.007

Al-Matari, E. M., \& Al-Arussi, A. S. (2016). The effect of the ownership structure characteristics on firm performance in oman: Empirical study. Corporate Ownership and Control, 13(2), 93-100. https://doi.org/10.22495/cocv13i2 p10

Al-Matari, E. M., Al-Matari, Y. A., \& Mohammed, S. A. S. (2017). Ownership structure, audit quality and firm performance moderating and direct-effect models: An empirical study. Corporate Board Role 
Duties and Composition, 13(1), 28-35. https:// doi.org/10.22495/cbv13i1p 3

AL-Najjar, D. (2015). The Effect of Institutional Ownership on Firm Performance: Evidence from Jordanian Listed Firms. International Journal of Economics and Finance, 7(12), 97.

https:// doi.org/10.5539/ijef.v7n12 p97

Cambrea, D. R., Lussana, G., Quarato, F., \& Varacca Capello, P. (2017). Top management team diversity and firm performance: Empirical evidence from the fashion and luxury industry. Corporate Ownership and Control, 15(1), 325-340. https:// doi.org/10.22495/cocv15i1c $2 \mathrm{p} 2$

Chung, K. H., \& Zhang, H. (2011). Corporate governance and institutional ownership. Journal of Financial and Quantitative Analysis, 46(1), 247-273. https://doi.org/10.1017/S00221090 10000682

Dewi, L. P. U. K., \& Wirasedana, I. W. P. (2018). Pengaruh Keputusan Investasi , Keputusan Pendanaan , Kebijakan Dividen dan Tingkat Inflasi Terhadap Nilai Perusahaan Luh Putu Utami Kartika Dewi 1 Fakultas Ekonomi dan Bisnis Universitas Udayana ( Unud ), Bali , Indonesia Fakultas Ekonomi dan Bisnis Unive. E-Jurnal Manajemen Universitas Udayana, 23(2), 813-841. https:// doi.org/10.24843/EJA.2018. v23.i02.p01

Eagly, A. H., \& Johnson, B. T. (1990). Gender and Leadership Style: A MetaAnalysis. Psychological Bulletin, 108(2), 233-256. https:/ / doi.org/10.1037/00332909.108.2.233

Esther, W. G., Symon, K. K., Lawrence, K. K., \& Sifunjo, E. K. (2016). The influence of ownership structure on financial performance of privatized companies in Kenya. African Journal of Business Management, 10(4), 75-88. https://doi.org/10.5897/ajbm2015. 7949

Francoeur, C., Labelle, R., \& SinclairDesgagné, B. (2008). Gender diversity in corporate governance and top management. Journal of Business Ethics, 81(1), 83-95. https://doi.org/10.1007/s10551007-9482-5

Gallego-Álvarez, I., García-Sánchez, I. M., \& Rodríguez-Dominguez, L. (2010). The influence of gender diversity on corporate performance. Revista de Contabilidad-Spanish Accounting Review, 13(1), 53-88. https://doi.org/10.1016/S11384891(10)70012-1

Giraldez-Puig, P., \& Berenguer, E. (2018). Family female executives and firm financial performance. Sustainability (Switzerland), 10(11). https://doi.org/10.3390/su1011416 3

Hambrick, D. C. (2007). Upper echelons theory: An update. Academy of Management Review, 32(2), 334-343. https://doi.org/10.5465/AMR.2007 .24345254

Hambrick, D. C. ., \& Mason, P. A. . (1984). Hambrick1984--

UpperEchelons_TheOrganizationa saReflectionofItsTopManagers.pdf.

The Acadamy of Management Review, Vol. 9, pp. 193-206.

Herdjiono, I., \& Sari, I. M. (2017). The effect of corporate governance on the performance of a company. Some empirical findings from Indonesia. Journal of Management and Business Administration. Central Europe, 25(1), 33-52.

https://doi.org/10.7206/jmba.ce.24 50-7814.188

Javed, T., Younas, W., \& Imran, M. (2014). Impact of Capital Structure on Firm Performance: Evidence from Pakistani Firms. International Journal of Academic Research in Economics and Management Sciences, 3(5), 28-52. 
https:// doi.org/10.6007/ijarems/v 3-i5/1141

Jensen, M. C. (1986). Agency costs of free cash flow, corporate finance, and takeovers. American Economic Review, $76(2)$, 323-329. https:// doi.org/10.1017/cbo978051 1609435.005

Jensen, M. C., \& Meckling, W. H. (1976). Theory of The Firm: Managerial Behavior, Agency Costs, and Ownership Structure. Journal of Financial Economics, 3(1976), 305-360.

Kao, M. F., Hodgkinson, L., \& Jaafar, A. (2018). Ownership structure, board of directors and firm performance: evidence from Taiwan. Corporate Governance (Bingley), 19(1), 189-216. https:// doi.org/10.1108/CG-042018-0144

Khamis, R., Hamdan, A. M., \& Elali, W. (2015). The relationship between ownership structure dimensions and corporate performance: Evidence from Bahrain. Australasian Accounting, Business and Finance Journal, 9(4), 38-56. https:/ / doi.org/10.14453/aabfj.v9i4 .4

Kusumastuti, S., \& Sastra, P. (2007). Pengaruh Board Diversity Terhadap Nilai Perusahaan Dalam Perspektif Corporate Governance. Jurnal Akuntansi Dan Keuangan, 9(2), 88-98. https:// doi.org/10.9744/jak.9.2.pp. 88-98

Marinova, J., Plantenga, J., \& Remery, C. (2016). Gender diversity and firm performance: evidence from Dutch and Danish boardrooms. International Journal of Human Resource Management, 27(15), 17771790.

https:/ / doi.org/10.1080/09585192.2 015.1079229

Nguyen, T. H., Nguyen, X. M., Nguyen, T. T. H., \& Tran, Q. T. (2017). Ownership structure and performance of professional service firms in a declining industry: Evidence from
Vietnamese securities firms. Business and Economic Horizons, 13(2), 142-151. https://doi.org/10.15208/beh.2017. 11

Nwude, E. C., Itiri, I. O., Agbadua, B. O., \& Udeh, S. N. (2016). The Impact of Debt Structure on Firm Performance: Empirical Evidence from Nigerian Quoted Firms. Asian Economic and Financial Review, 6(11), 647-660. https://doi.org/10.18488/journal.a efr/2016.6.11/102.11.647.660

Obembe, O. B., Olaniyi, C. O., \& Soetan, R. O. (2016). Managerial ownership and performance of listed nonfinancial firms in Nigeria. International Journal of Business and Emerging Markets, 8(4), 446. https:/ / doi.org/10.1504/ijbem.2016 .10000519

Pandey, K. D., \& Sahu, T. N. (2019). Debt Financing, Agency Cost and Firm Performance: Evidence from India. Vision, 23(3), 267-274. https://doi.org/10.1177/097226291 9859203

Perryman, A. A., Fernando, G. D., \& Tripathy, A. (2016). Do gender differences persist? An examination of gender diversity on firm performance, risk, and executive compensation. Journal of Business Research, 69(2), 579-586. https://doi.org/10.1016/j.jbusres.2 015.05.013

Sartini, L. P. N., \& Purbawangsa, I. B. A. (2014). Pengaruh Keputusan Investasi, Kebijakan Deviden, serta Keputusan Pendanaan terhadap Nilai Perusahaan Manufaktur di Bursa Efek Indonesia. Jurnal Manajemen, Strategi Bisnis Dan Kewirausahaan, 8(2), 81-91.

Sintyawati, N. L. A., \& Dewi, M. R. (2018). Pengaruh Kepemilikan Manajerial, Kepemilikan Institusional Dan Leverage Terhadap Biaya Keagenan Pada Perusahaan Manufaktur. EJurnal Manajemen Universitas Udayana, $\quad 7(2), \quad 933$. 
https:// doi.org/10.24843/EJMUNU D.2018.v7.i02.p16

Solakoglu, M. N., \& Demir, N. (2016). The role of firm characteristics on the relationship between gender diversity and firm performance. Management Decision, 54(6), 14071419.

Stulz, R. M. (1990). Managerial discretion and optimal financing policies. Journal of Financial Economics, 26(1), 3-27. https://doi.org/10.1016/0304405X(90)90011-N

Welbourne, T. M., Cycyota, C. S., \& Ferrante,
C. J. (2007). Wall street reaction to women in IPOs: An examination of gender diversity in top management teams. Group and Organization Management, 32(5), 524-547. https://doi.org/10.1177/105960110 6291071

Yazdanfar, D., \& Öhman, P. (2015). Debt financing and firm performance: an empirical study based on Swedish data. Journal of Risk Finance, 16(1), 102-118.

https://doi.org/10.1108/JRF-062014-0085 